\title{
Implementation of Early Childhood Development Integrative and Holistic (Paud Hi) in Daycare
}

\author{
Rohita, Nila Fitria, Nurfadilah \\ PG PAUD, Faculty of Psychology and Education, University of Al Azhar Indonesia, Indonesia \\ Corresponding e-mail: rohita@uai.ac.id
}

\begin{abstract}
Nowadays, social economic condition has created the need of day-care become higher, especially for working parents. It has made parents role shared to the caregiver, who can be educating, nurturing and protecting the children as well. Children can obtain a wide range of needs while their parents are working. The role of parents is temporarily replaced by trained educares who have the competence to educate, nurture and protect children. The purpose of this study is to describe the early childhood development services holistic and integrative (ECD HI) which provides by the caregiver in day-cares correspond to the policy of ECD HI. Day-care services in Indonesia has been conducted by several governances which lead to policy making, such as Presidential Regulation No.60/2013, about PAUD HI. The presidential regulation revealed that the definition of ECD HI is early childhood development efforts that are made to meet the essential needs of children are diverse and interrelated simultaneously, systematic and integrated. Furthermore, there is an international evidence that have shown that early childhood education program which integrates health and nutrition, and early childhood education intervention, have a greater impact than a program that only covers one aspect of children's services. The samples of this qualitative study were taken using the technique of purposive sampling because the sample was 2 (two) day-cares that have stated about ECD HI as their policy and located in government institution, in Jakarta. These day-care's licenses under the coordination of two different ministries, Ministry of Education and Culture and Ministry Social Services. All of the data that have been required was obtained through interviews, observations and papers documentation. The results showed that caregiver in both done has implemented ECD HI services with different qualities and some services are collaborating with other institution.
\end{abstract}

Keywords: $\quad$ Early Childhood Development Integrative Holistic, Day-care, Nurture

\section{INTRODUCTION}

\subsection{Background}

Some research shows that early childhood programs have a positive impact on children because it can help kids not to repeat a grade, follow special education, nor dropping out of school. Additionally, international evidence shows that early childhood education program which integrates health, nutrition, and early childhood education intervention, have a greater impact than a program that only covers one aspect of children's services (State Ministry for Development Planning [BAPPENAS], 2013).
However, there's few parents with young children who are able to full fill the needs of children to the maximum because of the social economic demands that require the parents, including mothers to work outside the home. Meanwhile nurturing, educating and raising children are basically the duty and responsibility of parents, especially in the early period of growth which is often referred to as the golden age.

Day-care becomes one of the alternatives that can be selected by parents to help them fulfil their tasks and responsibilities. The Ministry of Education and Culture (MoEC) uses the term "Taman Penitipan Anak" (TPA) for day-care, which is 
intended for children from birth up to the age of 6 (six) years. Meanwhile, the Ministry of Social Services (MoSS) uses the term "Taman Anak Sejahtera" (TAS) for children from 3 (three) months up to 8 (eight) years old.

The Ministry of National Development Planning has developed a national strategy ECD HI which is then translated again into the general guidelines document the implementation of ECD HI. In order to shade the coordination of various government sectors or ministries that have programs related institutions ECD HI, then issued Presidential Regulation no. 60 in 2013.

The Presidential Regulation No.60 Year 2013 about ECD HI, has also stated that ECD HI comprised of education, care services, health services, protection services and welfare services. In other words, that the development of a child would require a complete efforts (holistic) to make young generation with superior quality is possible.

Further described in the regulation that the ECD $\mathrm{HI}$ organized by the government, local governments and the public to follow the provisions of norms, standards, procedures and criteria, which includes the implementation of supervision, advocacy and training. Based on desktop review and interview, it is known that both Ministry of Education and Culture and Ministry of Social Service has stated ECD HI in their policies.

Licensing of TPA have been set in the Regulation of the Minister of Education and Culture of the Republic of Indonesia no. 84 of 2014, while standards implementation has been set in the Regulation of the Minister of Education and Culture of the Republic of Indonesia No. 137 of 2014, on the national standards of early childhood education. Additionally, Ministry of Education and Culture has their own norms, standards, procedures and criteria about Early Childhood Education Holistic Integrative (ECE HI) which was published in 2015. On the other hand, the only policy that Ministry of Social Service have about ECD HI, specifically in TAS, is the regulation of the Minister of Social Services of the Republic of Indonesia No. 02 of 2012.

\subsection{Research objectives}

Accordingly, the background that was mentioned above, the purpose of this study is as follows:

(1) To describe the implementation of PAUD HI which conducted by the caregiver in day-care which located in government institution in Jakarta
(2) To find out what has caused the implementation differences among day-care

\subsection{Formulation of the problem}

Considering the limitation of the research issues above, the formulation of the problem can be stated as follows:

(1) How is the implementation of PAUD HI which conducted by the caregiver in day-care which located in government institution in Jakarta?

(2) What have caused the implementation differences among day-care which located in government institution in Jakarta?

Ministry of Education and Culture has norms, standards, procedures and criteria about Early Childhood Education Holistic Integrative (ECE HI) which become referral for all ECD unit. It consists of policies, principles, the role of the parties that related to the implementation of ECD HI, the provision of ECD HI, monitoring, evaluation and reporting.

\section{THEORETICAL STUDIES}

\subsection{Early childhood development services holistic and integrative (ECD HI)}

Refer to Presidential Regulation no. 60 in 2013, the definition of ECD HI is early childhood development efforts that are made to meet the essential needs of children are diverse and interrelated simultaneously, systematic and integrated. This definition is in line with ecological systems theory, which explain on how everything in a child and the child's environment affects how a child grows and develops.

The ECD HI is planned in a systematic and applied systemically in ECD unit to optimize the potential of growth and development of children optimally in order to later be child quality and competitiveness in the future. Furthermore, those concepts shown the embodiment of what is proposed by Myers (1992), who stated that in making planning and implementing programmes of early childhood care and development, need to consider three things, there are:

(1) Variations in a child's developmental status

(2) Complementary program approaches

(3) Program characteristics/guidelines.

It is showed in figure 1 below. 


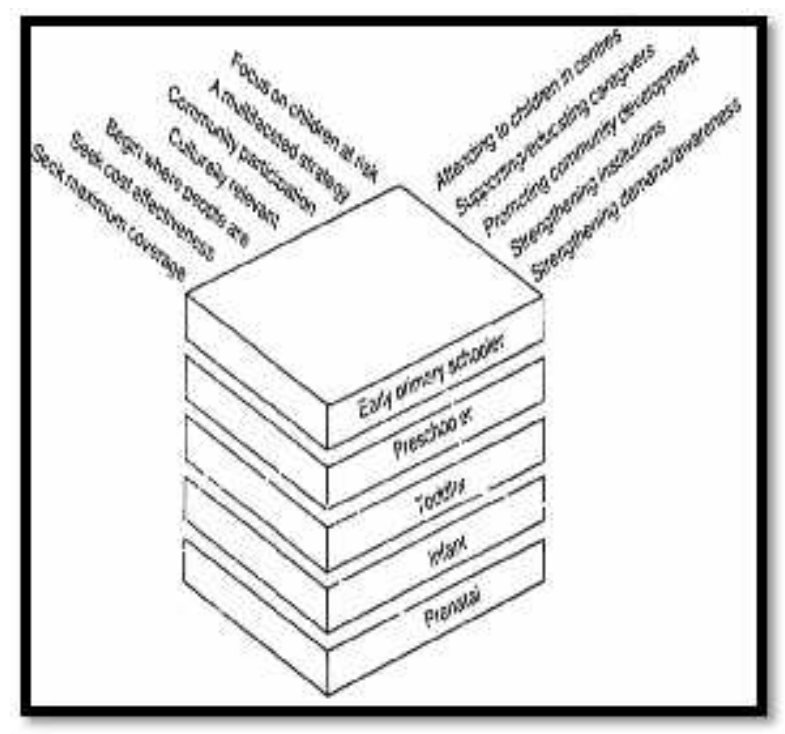

Figure 1. Programming for ECD: a comprehensive framework

\subsection{Daycare}

Providing the service needs of children in the TPA is performed by skill full caregiver. There are some terms that have been used for educator in day-care, such as educare, caregiver and facilitator.

Caregivers are the experience, skills, and responsibilities as parents in educating and caring for children (Hastuti, 2010). Meanwhile, according to MoEC policy, caregiver is someone who has the ability to provide care and treatment services to children to replace the role of parents who are working/trying to earn for a living.

The caregiver whom are working in the day-care has an obligation to provide a variety of activities and the needs for foster children during the child is in the day-care. It is as it says by Hoghughi and Long (2004) that care includes a variety of activities aimed for children to develop optimally and can survive well. The principle of parenting according to Hoghughi has no emphasis on who (actors), but more emphasis on the activities of the development and education of children. Therefore, care includes physical care, emotional care and social care.

Meanwhile, Jerome Kagan (in Berns, 2013), a development psychologist stated that parenting as a series of decisions on the socialization of children, which includes what is to be done by parents/educares so that children are able to be responsible and become a contributing member of society as well as what should parents/educares do when children cry, feel angry, lie, and do not perform their obligations properly.
According to Regulation of the Minister of Education and Culture of the Republic of Indonesia No. 137 of 2014, a caregiver is equivalent to young teacher assistant. The regulation mentions the minimum standard of the qualification and competence to be a caregiver.

Furthermore, Surya (2007) stated that the capability on becoming a caregiver needs requirements as follows:

(1) Knowledge about health.

(2) The ability to speak clearly and politely.

(3) Have a high enough intelligence

(4) Behave in a polite and courteous manner.

\section{METHODS}

The method that is used is qualitative research method, where researchers want to describe the services of the early childhood development holistic and integrative which are done by educates is in accordance with the policy of the development of Early Childhood Holistic and Integrative. The subjects of this study are 2 TPA institutions which are the Public University and the State Government in Jakarta. Data were collected using interview, observation, and documentation. The guidelines were developed based on MoEC's norms, standards, procedures and criteria about Early Childhood Education Holistic Integrative (ECE HI) because the MoSS have not been published yet. The collected data were analysed using descriptive qualitative, so that it can answer the problems that were present.

\section{RESULT}

The result of the study is described as follows: a. Daycare at public university

Educator in this TPA were called as educare, so we used that term in result.

(1) Education services Education services were given in a form of stimulation that is developmentally appropriate and done by the educares on doing fun activities in a conducive situation based on the principles that apply.

(2) Health and nutrition services

Measuring the height, weight and head circumference of a child and when a child is sick, educare only dare to give a medicine like "cooling gel sheet" for fever or they will refer to the clinic. If the child refer to the clinic, the educare 
confirmed to teh parents first. Besides, educare gives some food considering balanced nutrition.

(3) Nurture services

Educare holding a parenting program which are carried out every 4 months within a period of 1 year. The involvement of parents is not just in parenting program, but also in learning activities.

(4) Protection and welfare services Educare ensure that the environment and learning materials that will be used by the children in good condition, safe and healthy. Additionally, the toys that are provided are considering the existing national standards, which called as SNI and ISO.

Furthermore, educare also make sure no children are exposed to physical or verbal abuse either from friends.

\section{b. Daycare at the state government in Jakarta}

(1) Education services

Educational service was given based on stimulation given to the child and giving opportunities for children to freely choose their toys.

(2) Health and nutrition services

Educare does not provide health care and nutrition. Weighing and height measurement used to be done, but knows only recorded in the book based on secondary information. Handwashing, personal and environment hygiene has been taught trough habituation.

(3) Nurture services

Nurture services is given by the educare by doing counselling activates, discussion, simulations, seminars, with topics: child's growth and development; introducing a healthy meal; "PHBS", prevention of intestinal worms, and the use of iodizes salt.

(4) Protection and welfare services

Educare provide guidance to children on how to use toys that are safe and healthy. Educares also introduce the children about parts of the body as a way to protect the children from the unsafe and uncomfortable treatment by others to their body but educares do not identify whether there are children who had unpleasant treatment.

welfare services are more about the habituation for educares to give praise, star, or reward to the child also providing assistance to families of children who do not have birth certificates and do not have access to health care. yet, the day-care at the state government does not accept children with special needs due to limited capabilities and knowledge.

\section{DISCUSSION}

The results can be describing through the table as follows:

Table 1. Services in TPA at Public University

\begin{tabular}{|c|c|}
\hline \multicolumn{2}{|c|}{ TPA at Public University in Jakarta } \\
\hline $\begin{array}{l}\text { Health and } \\
\text { nutrition }\end{array}$ & $\begin{array}{l}\text { 1. Measuring, height, weight, head } \\
\text { circumference } \\
\text { 2. Additional nutritious food and } \\
\text { drink } \\
\text { 3. Case referral to clinic (accident } \\
\text { /sick) based on parent 's approval } \\
\text { and puskeesmas for immunization } \\
\text { 4. Involving medical personnel in } \\
\text { screening child growth and } \\
\text { development then communicate the } \\
\text { result to parents } \\
\text { 5. Health record }\end{array}$ \\
\hline Education & $\begin{array}{l}\text { 1. Implementing early childhood } \\
\text { learning context } \\
\text { 2. Using } 2013 \text { curriculum } \\
\text { 3. Involving college student Involving } \\
\text { parents in certain subject as } \\
\text { supporting teacher }\end{array}$ \\
\hline Nurturing & $\begin{array}{l}\text { Conducting parenting program } 3 \\
\text { (three) times per year }\end{array}$ \\
\hline $\begin{array}{l}\text { Protection and } \\
\text { welfare }\end{array}$ & $\begin{array}{l}\text { 1. Most of the toys are having SNI } \\
\text { certification } \\
\text { 2. Psychoeducation with one of the } \\
\text { theme is body protection and what } \\
\text { to do when feel child unpleasant } \\
\text { 3. The setting of the learning } \\
\text { properties and media is age } \\
\text { appropriate and under caregiver } \\
\text { supervision }\end{array}$ \\
\hline
\end{tabular}


Table 2. Services in day-care at the State Government

\begin{tabular}{|l|l|}
\hline \multicolumn{3}{|c|}{ TPA at the State Government in } \\
Jakarta \\
\hline $\begin{array}{l}\text { Health and } \\
\text { nutrition }\end{array}$ & $\begin{array}{l}\text { 1. } \\
\text { Recording child height and weight } \\
\text { based on parent's information } \\
\text { Involving clinic and medical } \\
\text { personnel to screening child } \\
\text { growth and development then } \\
\text { report the results to parents }\end{array}$ \\
\hline Education & $\begin{array}{l}\text { 1. } \\
\text { 2. }\end{array}$ \\
\hline Nurturing play \\
\hline $\begin{array}{l}\text { Unplanned activity } \\
\text { Psychoeducation to parents with } \\
\text { child growth and development as the } \\
\text { topic but unscheduled }\end{array}$ \\
\hline $\begin{array}{l}\text { 1. } \\
\text { and were's no special intervention for } \\
\text { protection case }\end{array}$ \\
\hline 2. $\begin{array}{l}\text { Psychoeducation with one of the } \\
\text { theme is body protection without } \\
\text { giving information about what } \\
\text { child can do }\end{array}$
\end{tabular}

Based on the four services described above, it can be said that in accordance with MoEC's norms, standards, procedures and criteria about Early Childhood Education Holistic Integrative (ECE HI) the characteristics of ECD HI both institutions lack on involving parents, caregivers and communities to strengthen family support. Besides day-care should also be able to provide services for children with special needs as good as for other children in general.

\section{CONCLUSION}

The results showed that caregiver in both day-cares has implemented ECD HI with different qualities and some of the services has collaborated with other institution. These conditions need further study with a bigger sample so the implementation of ECD HI can be implemented in any sectors that are related for the sake of the children's future. Furthermore, we can conclude that:

1. TPA at Public University have been carrying out activities in accordance with HI early childhood policies, especially the ones that published by MoEC.

2. TPA at the State Government in Jakarta still not optimal on providing services, because the policy that was set by MoSS was not as complete as the MoEC. MoSS can adopt what has been done by MoEC to enhance existing condition.

\section{ACKNOWLEDGEMENT}

This research was conducted with research grant from Ministry of Research, Technology and Higher Education and supported by The Institute for Research and Community Service (LP2M) University of Al Azhar Indonesia.

\section{REFERENCES}

Berns, Roberta M. (2013). Child, Family, Community Sosialization and Support. USA: Belmont.

Hastuti, Dwi (2010). Pengasuhan : Teori, Prinsip dan Aplikasinya di Indonesia. IPB Press.Bogor.

Hoghughi, Masud and Nicholas Long. (2004). Handbook of Parenting: theory and research for practice. UK: SAGE Publications Ltd.

Myers, Robert. G. (1992). Twelve Who Survive. Routledge. New York

Surya, Sutan. (2007). Melejitkan Multiple Intelligence Anak Sejak Dini. Yogyakarta: Andi. .(2015). NSPK: Petunjuk Teknis

Penyelenggaraan PAUD HI di Satuan PAUD. Kementerian Pendidikan dan Kebudayaan RI. Jakarta.

. (2015). Petunjuk Teknis

Penyelenggaraan Taman Penitipan Anak. Kementerian Pendidikan dan Kebudayaan RI. Jakarta

.(2014). Peraturan Menteri Pendidikan

Nasional Republik Indonesia No. 137 Tahun 2014 tentang Standar Pendidikan Anak Usia Dini tentang pendirian PAUD. Jakarta . (2014). Peraturan Menteri Pendidikan Nasional Republik Indonesia No. 137 Tahun 2014 tentang Standar Pendidikan Anak Usia Dini. Jakarta .(2013). Studi Pengembangan Anak Usia Dini. BAPPENAS. Jakarta. (2013). Peraturan Presiden No.60 Tahun 2013 tentang Pengembangan Anak Usia Dini Holistik Integratif (AUD HI). Jakarta. . (2010). Publication Manual of The American Psychological Association (6th edition). American Psychological Association. Washington DC

.(2009). Pedoman Umum Pengembangan Anak Usia Dini Holistik Integratif. BAPPENAS. Jakarta. 